\title{
Thermobacillus xylanilyticus gen. nov., sp. nov., a new aerobic thermophilic xylan-degrading bacterium isolated from farm soil
}

\author{
Jean Pierre Touzel, ${ }^{1}$ Michael O'Donohue, ${ }^{1}$ Philippe Debeire, ${ }^{1}$ \\ Eric Samain ${ }^{2}$ and Christelle Breton ${ }^{2}$
}

\footnotetext{
1 INRA (Institut National de la Recherche Agronomique), Unité de Physicochimie et Biotechnologie des Polymères, Équipe de Fractionnement Enzymatique, BP 1039, F-51687 Reims cedex 2, France

2 Centre de Recherches sur les Macromolécules Végétales (CERMAV-CNRS) BP 53, F-38041 Grenoble cedex 9, France
}

Author for correspondence: Jean Pierre Touzel. Tel: +33 32691 3150. Fax: + 33326913887. e-mail: touzel@lille.inra.fr

\begin{abstract}
An aerobic, thermophilic, xylanolytic, spore-forming bacterium, $\mathrm{XE}^{\mathrm{TP}}(\mathrm{T}=$ type strain; $P$ = patent strain), has been isolated from farm soil situated underneath a manure heap in northern France. Strain $\mathrm{XE}^{\mathrm{TP}}$, which stained negative in the Gram test, occurs as short rods which sometimes form chains. Its spores are ellipsoidal, central to subterminal and occur in swollen sporangia. It grows at temperatures up to $63^{\circ} \mathrm{C}$ and in the $\mathrm{pH}$ range 6.5-8.5. When grown on glucose in optimal conditions, its doubling time was found to be $33 \mathrm{~min} . \mathrm{CO}_{2}$ was observed to have a growth-stimulating effect at the start of the culture. In addition to glucose, the isolate utilizes xylose, arabinose, mannose, cellobiose, galactose, maltose, sucrose, xylan and starch. Growth is inhibited by $5 \% \mathrm{NaCl}$. The $\mathrm{G}+\mathrm{C}$ content of strain $\mathrm{XE}^{\mathrm{TP}}$ is $57.5 \mathrm{~mol} \%$. The $16 \mathrm{~S}$ rDNA sequence analysis indicated that strain $\mathrm{XE}^{\mathrm{TP}}$ falls into the radiation of the Bacillus-Lactobacillus-Streptococcus subdivision of the Gram-positive phylum. Its three closest phylogenetic relatives are 'Bacillus viscosus', Paenibacillus curdlanolyticus and Bacillus popilliae with identity values of 91.15, 90.94 and $90.92 \%$, respectively. The major cellular fatty acids are 14-methyl pentadecanoic acid (16:0 iso), hexadecanoic acid (16:0) and 14-methyl hexadecanoic acid (17:0 anteiso). On the basis of 16S rRNA sequence and chemotaxonomic characteristics, the isolate is different enough for it to be considered as a member of a new genus. It is therefore proposed that this isolate represents a new genus and species: Thermobacillus xylanilyticus. Strain XE ${ }^{\mathrm{TP}}$, the type strain of Thermobacillus xylanilyticus, has been deposited in the Collection Nationale de Cultures Microbiennes (CNCM I-1017) as a patent strain.
\end{abstract}

Keywords: Thermobacillus xylanilyticus, thermophile, xylanolytic bacterium

\section{INTRODUCTION}

Thermophilic micro-organisms are of special interest to enzymologists both at the fundamental and industrial level as a natural source of enzymes that are active and stable at high temperatures (Zeikus, 1979; Bergquist et al., 1989). Enzymes that take part in the biodegradation of plant cell-wall polymers, i.e. cellulose and hemicellulose have attracted much attention in past decades because they can be useful in fields as diverse as production of fuels or chemicals

The EMBL accession number for the $16 \mathrm{~S}$ rDNA sequence of Thermobacillus xylanilyticus strain $\mathrm{XE}^{\mathrm{TP}}$ is AJ005795. such as ethanol or lactate from plant biomass (Lamed et al., 1988), bio-bleaching of paper pulps (Mora et al., 1986; Noé et al., 1986; Viikari et al., 1994; Wong et al., 1996), animal feed additives (Annison, 1992; Classen, 1996) and breadmaking (Maat et al., 1992; Rouau et al., 1994). Moreover, the interest in enzymes with adequate thermostability is of importance for industrial applications (Wassermann, 1984).

During the course of our search for aerobic thermophilic bacteria able to degrade xylans, such a bacterium was isolated from a soil sample taken from beneath a manure heap in a farm in northern France. It was enriched in several steps using liquid medium containing xylan from oat spelts as the main carbon source 
(Samain et al., 1992). This strain, called $\mathrm{XE}^{\mathrm{TP}}$, is unique in that it is able to produce high levels of an extracellular $20 \mathrm{kDa}$ endoxylanase in about $16 \mathrm{~h}$ of cultivation at $55^{\circ} \mathrm{C}$ (Samain et al., 1997). As an aerobic spore-former, the isolate was tentatively identified as Bacillus sp. The isolate has been patented together with a mutant thereof, the strain D3, obtained by mutagenesis with ethylmethanesulfonate (Samain et al., 1991). This paper deals with the characterization and taxonomy of the strain $\mathrm{XE}^{\mathrm{TP}}$, which does not appear to fit into any of the new genera arising from the splitting of the genus Bacillus.

\section{METHODS}

Culture conditions. For stock maintenance and experimental studies, strains were cultivated in a basal medium having the following composition $\left(1^{-1}\right)$ : $0.3 \mathrm{~g} \mathrm{KH}_{2} \mathrm{PO}_{4}, 0.6 \mathrm{~g} \mathrm{NaCl}$, $0 \cdot 12 \mathrm{~g} \mathrm{MgSO}_{4} .7 \mathrm{H}_{2} \mathrm{O}, 0.08 \mathrm{~g} \mathrm{CaCl}_{2} .2 \mathrm{H}_{2} \mathrm{O}, 1 \mathrm{~g} \mathrm{NH} \mathrm{Nl}_{4}, 2 \mathrm{~g}$ yeast extract, $10 \mathrm{ml}$ vitamin solution and $10 \mathrm{ml}$ trace mineral solution. Vitamin and trace mineral solution were prepared according to Zeikus \& Wolfe (1972). An appropriate carbon source was added at a concentration of $2 \mathrm{~g} \mathrm{l}^{-1}$. The $\mathrm{pH}$ was brought to 7 with $\mathrm{NaOH}$, then $5 \mathrm{~g} \mathrm{KHCO}_{3} 1^{-1}$ was added. The medium was dispensed in $10 \mathrm{ml}$ aliquots in $125 \mathrm{ml}$ serum bottles equipped with rubber septa and crimped aluminium seals. Before sealing and autoclaving, $10 \mathrm{ml} \mathrm{CO}_{2}$ was injected into the headspace of bottles with a syringe. Inoculation $(1 \%, v / v)$ was made by injection with a syringe through the rubber septum. Cultures were grown overnight at $55^{\circ} \mathrm{C}$ on a rotary shaker at 200 r.p.m. Liquid stock cultures grown on glucose remained viable when kept at $4{ }^{\circ} \mathrm{C}$ for periods exceeding one year. When required, the basal medium was solidified with $17 \mathrm{~g}$ agar $1^{-1}$; the Petri dishes were incubated in a sealed container with about $10 \% \mathrm{CO}_{2}$ in the gas phase. $\mathrm{J}$-agar was also used as an alternative solid medium for observing the colony shape.

Growth experiments, physiological and biochemical characterization. Substrate utilization analysis was performed in duplicate in $125 \mathrm{ml}$ serum bottles containing $10 \mathrm{ml}$ basal medium supplemented with different carbon sources, each to a final concentration of $2 \mathrm{~g} \mathrm{l}^{-1}$. All cultures were incubated at $55^{\circ} \mathrm{C}$ for up to $3 \mathrm{~d}$. Growth was monitored by OD measurements at $540 \mathrm{~nm}$. The basal medium containing $2 \mathrm{~g}$ glucose $1^{-1}$ was used for testing growth in the presence of $\mathrm{NaCl}$. The same medium was used for the determination of temperature and $\mathrm{pH}$ growth ranges. Due to the peculiar requirement for $\mathrm{CO}_{2}$, the different $\mathrm{pH}$ values ranging from 6.5 to 8.6 at $55^{\circ} \mathrm{C}$ at the start of the culture were obtained by varying the concentration of $\mathrm{KHCO}_{3}$. Tests for swimming motility, oxygen relationships, catalase, oxidase, urease, aesculin hydrolysis and nitrate reduction were conducted according to Smibert \& Krieg (1994).

Gram reaction and general morphology. Smears for Gram staining were performed using overnight cultures. The Bacto 3-Step Gram Stain Set-S (Difco) was used according the manufacturer's instructions. Cell morphology was examined by phase-contrast microscopy (Nikon Optiphot-2). Colonies were observed using a stereoscopic microscope (Nikon SMZ-10A). The presence of flagella was sought using scanning electron microscopy with cells from overnight cultures as the sample. These cells were fixed for $30 \mathrm{~min}$ with $2.5 \%$ glutaraldehyde in $0.2 \mathrm{M}$ PBS $(0.145 \mathrm{M} \mathrm{NaCl}, 0.15 \mathrm{M}$ sodium phosphate, $\mathrm{pH} 7 \cdot 2$ ), deposited onto a polylysincoated glass slide and post-fixed for $1 \mathrm{~h}$ in $2 \%(\mathrm{w} / \mathrm{v})$ osmium tetroxide in water. After critical-point drying, the preparation was metal-shadowed with gold/palladium and examined using a model JSM-5400LV (JEOL) scanning electron microscope at $15 \mathrm{kV}$.

Fatty acids and quinone analysis. Analyses were performed by the DSMZ Identification Service (German Collection of Microorganisms, Braunschweig, Germany) using the extraction procedure of Minnikin et al. (1984). Fatty acids were determined by GC and menaquinone by HPLC (Kroppenstedt, 1985) on freeze-dried cells grown on glucose in the standard medium.

DNA isolation and base composition. DNA was isolated as described by Touzel et al. (1992). The G+C content was determined by melting point analysis (Marmur \& Doty, 1962), with Escherichia coli DNA (50 $\mathrm{mol} \% \mathrm{G}+\mathrm{C})$ as a reference.

16S rRNA gene sequencing. 16S rDNA was amplified from $\mathrm{XE}^{\mathrm{TP}}$ genomic DNA by PCR (Mullis \& Faloona, 1987; Saiki et al., 1988). The primers employed were 5'-AGA GTT TGA TCC TGG CTC AG-3' and 5'-AAG GAG GTG ATC CAG CC-3' (Wisotzkey et al., 1992) which correspond to positions 8-27 and 1541-1525 in the 16S rRNA (E. coli numbering; Brosius et al., 1978). The sequences of both strands of the PCR-amplified 16S DNA (1554 bp) were determined using the dideoxy sequencing method (Sanger et al., 1977) supplied in kit form (Ladderman; Takara Shuzo). Sequence assembly of the various contiguous sequences was performed using the SeqMan module of the DNASTAR Lasergene package.

Sequence analysis. The $16 \mathrm{~S}$ rRNA gene sequence was compared to sequences available in the prokaryote subset (EMPRO) and the latest entries (EMNEW) of the EMBL database using FASTA3 (Pearson \& Lipman, 1988; Pearson, 1990) through on-line access to the European Bioinformatics Institute World Wide Web server. The sequence was also analysed using Sequence Match, Distance Matrix and other on-line services provided by the RDP-II server (Maidak et al., 1997). A phylogenetic analysis was performed on a set of selected sequences spanning all the groups of the former Bacillus genus including the three closest neighbours of strain $\mathrm{XE}^{\mathrm{TP}}$ found by FASTA3 and E. coli. A total of 18 sequences were aligned using PILEUP [Wisconsin Package Version 9.0, Genetics Computer Group (GCG), Madison, WI, USA]. Nucleotide positions that could be unambiguously aligned for all $16 \mathrm{~S}$ rRNA genes compared were included in the analysis. The final data comprised $1421 \mathrm{nt}$ positions corresponding to positions 46-1466 of the alignment. The distances were calculated using DISTANCES (GCG) with the two-parameter correction method (Kimura, 1980). A tree was built using TREECON 1.2 for Windows (Van de Peer \& De Wachter, 1994) by the neighbour-joining method. Other nucleotide sequences, obtained from the EMBL database, had the following accession numbers: X76436 (Bacillus alcalophilus DSM 485 ${ }^{\mathrm{T}}$ ); D78312 (Bacillus circulans IAM 12462 ${ }^{\mathrm{T}}$ ); X68415 (Bacillus globisporus DSM 4 ${ }^{\mathrm{T}}$ ); X60618 (Bacillus kaustophilus NCIMB 8547"T); X60631 (Bacillus pasteurii NCIMB 8841 ${ }^{\mathrm{T}}$ ); AF071859 (Bacillus popilliae ATCC $4706^{\mathrm{T}}$ ); K00637 (Bacillus subtilis W168PY79); X60641 (Bacillus thermoglucosidasius ATCC 43742 ${ }^{\mathrm{T}}$ ); X77792 ('Bacillus viscosus' ATCC 51155); X60612 (Brevibacillus brevis NCIMB 9372 ${ }^{\mathrm{T}}$ ); X60620 (Brevibacillus laterosporus NCDO 1763); X60627 (Virgibacillus pantothenticus NCDO 1765); X60606 (Paenibacillus amylolyticus NCIMB 8144); D78466 (Paenibacillus curdlanolyticus IFO $15724^{\mathrm{T}}$ ); X57306 (Paenibacillus macerans ATCC 8244 ${ }^{\mathrm{T}}$ ); and D16276 (Paenibacillus polymyxa IAM 13419 $)$. 


\section{RESULTS}

\section{Morphological and physiological characteristics}

Cells from cultures grown for $7 \mathrm{~h}$ at $55^{\circ} \mathrm{C}$ were observed as thin rods measuring $0 \cdot 4-0.5$ by $2 \cdot 0-2 \cdot 8 \mu \mathrm{m}$. (Fig. 1a). They occurred singly, in pairs and occasionally in chains. After about $15 \mathrm{~h}$, they produced terminal or subterminal ellipsoidal spores in swollen sporangia. (Fig. 1b, c). Colonies exhibited an irregular, flat morphology and had rather undulate margins (Fig. 1d). Strain $\mathrm{XE}^{\mathrm{TP}}$ was found to be strictly aerobic, Gram-negative and non-motile. The measurement of catalase activity for this strain was positive, but no oxidase or urease activity was measured. Strain $\mathrm{XE}^{\mathrm{TP}}$ was able to grow in the presence of $\mathrm{NaCl}$ up to $3 \%$ $(\mathrm{w} / \mathrm{v})$ and was found to degrade both starch and aesculin but not gelatin or casein. Nitrate is not reduced. This strain grew optimally at $\mathrm{pH} 7 \cdot 8$ and $55^{\circ} \mathrm{C}$ whereas its $\mathrm{pH}$ and temperature limits are $\mathrm{pH} 6.5$ (lower), $\mathrm{pH} 8.5$ (higher) and $63{ }^{\circ} \mathrm{C}$, respectively. $\mathrm{CO}_{2}$ and hydrogen carbonate were found to be necessary for normal growth. Their omission resulted in an increased lag phase and overall poor growth. The following compounds were assimilated within $24 \mathrm{~h}$ : cellobiose, galactose, lactose, mannose, melibiose, raffinose, starch, trehalose and xylose. Fructose,
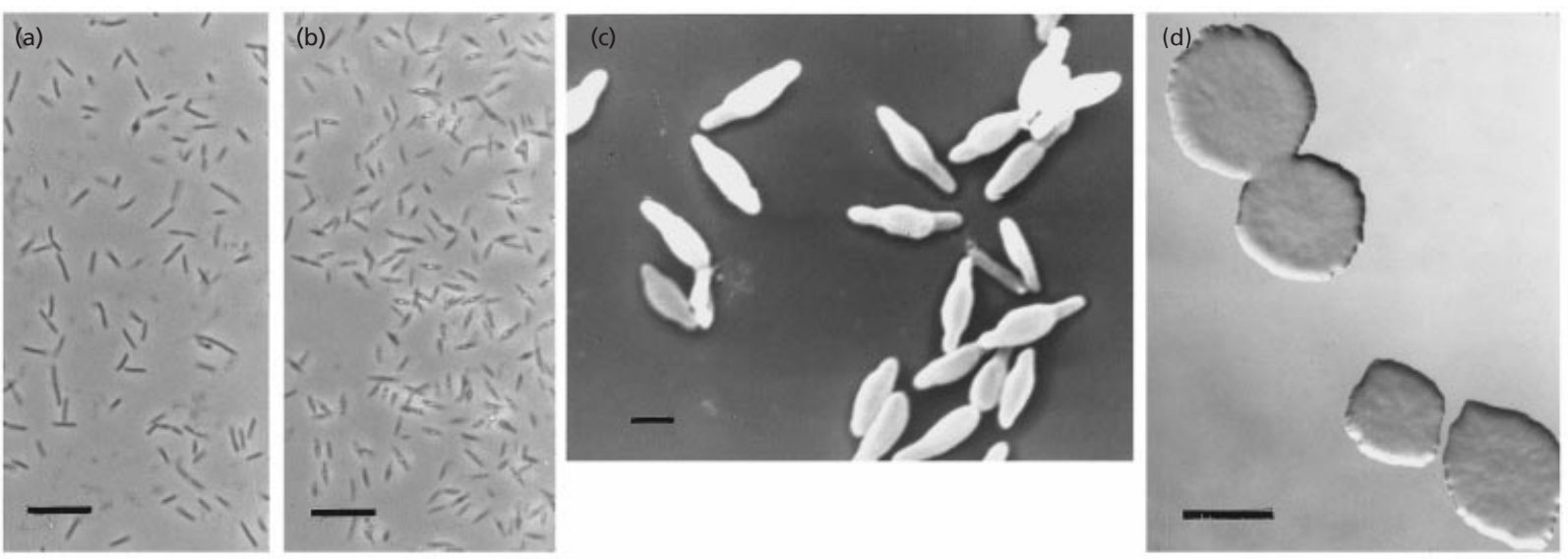

Fig. 1. Microscopic images of strain $X E^{T P}$. Phase-contrast micrographs of (a) cells in the vegetative state after a $7 \mathrm{~h}$ growth period in a liquid medium containing xylan and (b) sporulating cells from the same culture after a $15 \mathrm{~h}$ growth period; bar, $10 \mu \mathrm{m}$. (c) SEM image of cells in late-exponential growth phase displaying the swollen sporangia; bar, $1 \mu \mathrm{m}$. (d) Colonies grown for $2 \mathrm{~d}$ on J-agar; bar, $2 \mathrm{~mm}$.

Table 1. Cellular fatty acid composition (\%) of strain $\mathrm{XE}^{\mathrm{TP}}$ and some representatives of the genus Paenibacillus

The three major fatty acids are shown in bold.

\begin{tabular}{|llcc|}
\hline Fatty acid & Short designation & \multicolumn{2}{c|}{ Fatty acid composition (\%, w/w) } \\
\cline { 3 - 4 } & & Strain XE $^{\text {TP }}$ & Paenibacilli* \\
\hline 12-Methyl tridecanoic acid & $14: 0$ iso & $1 \cdot 0$ & $0 \cdot 6-7 \cdot 2$ \\
Tetradecanoic acid & $14: 0$ & $1 \cdot 2$ & $1 \cdot 2-3 \cdot 3$ \\
13-Methyl tetradecanoic acid & $15: 0$ iso & $0 \cdot 9$ & $\mathbf{1 0 \cdot 5}-\mathbf{3 4 \cdot 3}$ \\
12-Methyl tetradecanoic acid & $15: 0$ anteiso & $8 \cdot 7$ & $\mathbf{2 8 \cdot 2 - 5 7 \cdot 3}$ \\
Pentadecanoic acid & $15: 0$ & $1 \cdot 8$ & $0 \cdot 6-6 \cdot 7$ \\
14-Methyl pentadecanoic acid & $16: 0$ iso & $\mathbf{4 8 \cdot 0}$ & $2 \cdot 9-4 \cdot 5$ \\
Hexadecanoic acid & $16: 0$ & $\mathbf{2 1 \cdot 4}$ & $\mathbf{8} \cdot \mathbf{1}-\mathbf{2 8 \cdot 0}$ \\
15-Methyl hexadecanoic acid & $17: 0$ iso & $1 \cdot 8$ & $1 \cdot 0-6 \cdot 9$ \\
14-Methyl hexadecanoic acid & $17: 0$ anteiso & $\mathbf{1 2 \cdot 4}$ & $1 \cdot 3-12 \cdot 8$ \\
Heptadecanoic acid & $17: 0$ & $0 \cdot 9$ & \\
17-Methyl heptadecanoic acid & $18: 0$ iso & $1 \cdot 1$ & \\
Octadecanoic acid & $18: 0$ & $0 \cdot 7$ & \\
\hline
\end{tabular}

* Data obtained from Heyndrickx et al. (1996). The range for four different species (P. larvae, $P$. pulvifaciens, $P$. alvei and $P$. laterosporus) is given. 


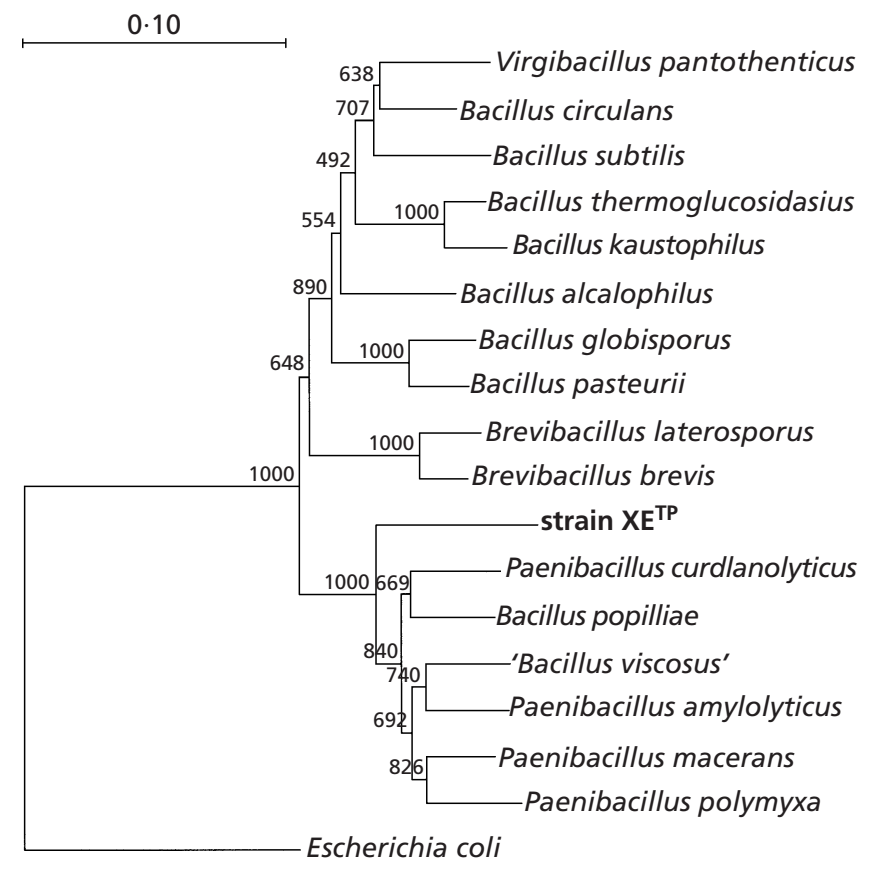

Fig. 2. Phylogenetic tree based on $16 \mathrm{~S}$ rDNA sequences comparisons of strain $\mathrm{XE}^{\mathrm{TP}}$ and selected bacteria from the Bacillus group. Bar, 10 base substitutions per 100 nucleotides. The numbers at each node are bootstrap values based on 1000 resamplings.

melezitol and tributyrin were assimilated within $48 \mathrm{~h}$, whereas adonitol, casein, citrate, dextrin, dulcitol, erythritol, gelatin, inulin, salicin, sorbitol and succinate remained unassimilated after $72 \mathrm{~h}$.

\section{Chemotaxonomic characteristics and DNA base composition}

The major isoprenoid quinone found in strain $\mathrm{XE}^{\mathrm{TP}}$ was MK-7, a 2-methyl 1,4 naphthoquinone showing a polyisoprenoid chain (7 units) in position 3. MK-7 is the major menaquinone generally found in aerobic, endospore-forming rods. The major cellular fatty acids were 14-methyl pentadecanoic acid (16:0 iso), hexadecanoic acid (16:0) and 14-methyl hexadecanoic acid (17:0 anteiso) (Table 1).

The $\mathrm{G}+\mathrm{C}$ content of strain $\mathrm{XE}^{\mathrm{TP}}$ was $57.5 \mathrm{~mol} \%$.

\section{Phylogenetic analysis}

An almost complete 16S rDNA sequence (1554 bp), which corresponds to a region between positions 8 and 1525 by comparison with the $E$. coli $16 \mathrm{~S}$ rRNA gene (Brosius et al., 1978), was directly sequenced. 16S rDNA alignments showed that the closest relatives of strain $\mathrm{XE}^{\mathrm{TP}}$ were 'Bacillus viscosus', Paenibacillus curdlanolyticus and Bacillus popilliae with identity values of $91 \cdot 15,90.94$ and $90.92 \%$, respectively. The phylogenetic tree (Fig. 2), constructed from the se- quence data, shows the position of strain $\mathrm{XE}^{\mathrm{TP}}$ within the group of selected species of Bacillus sensu lato including its three closest relatives.

\section{DISCUSSION}

The definitive taxonomic position of strain $\mathrm{XE}^{\mathrm{TP}}$ was impossible to establish by traditional methods. Indeed, this approach led to the classification of strain $\mathrm{XE}^{\mathrm{TP}}$ as a thermophilic member of the genus Bacillus where all aerobic, endospore-forming organisms have been classified (Yoon et al., 1998). For many years, the genus Bacillus was considered to be taxonomically heterogeneous (Sneath, 1986). Recently this genus was split, giving rise to several genera which were defined using 16S RNA sequence data. To date, five new genera have been recognized. They are: Alicyclobacillus (Wisotzkey et al., 1992), Aneurinibacillus (Shida et al., 1996), Brevibacillus (Shida et al., 1996), Paenibacillus (Ash et al., 1993) and Virgibacillus (Heyndrickx et al., 1996).

The results of $16 \mathrm{~S}$ rDNA sequencing for strain $\mathrm{XE}^{\mathrm{TP}}$ showed that its closest relatives are 'Bacillus viscosus', Paenibacillus curdlanolyticus and Bacillus popilliae with similarities below $92 \%$. 'Bacillus viscosus' has never been validly described and, like Bacillus popilliae, probably belongs to the genus Paenibacillus (Fig. 2). However strain $\mathrm{XE}^{\mathrm{TP}}$ can be clearly distinguished from the genus Paenibacillus: 16S rDNA sequence similarity is low; its $\mathrm{G}+\mathrm{C}$ content is well out of the range 45-54 mol\% for Paenibacillus (Shida et al., 1997); and its major cellular fatty acid is 16:0 iso compared to 15:0 anteiso for Paenibacillus (Shida et al., 1997). Moreover, the optimum growth temperature of 19 species (all species except Paenibacillus macquariensis) is $28-30{ }^{\circ} \mathrm{C}$, the optimum growth temperature being $20-23^{\circ} \mathrm{C}$ for Paenibacillus macquariensis (Shida et al., 1997). Finally, strain $\mathrm{XE}^{\mathrm{TP}}$ displays 16:0 iso as its main fatty acid, a feature not only unusual for the genus Paenibacillus (Shida et al., 1997) but equally unusual for the genus Bacillus as a whole (Kämpfer, 1994).

The phenotypic, chemotaxonomic and phylogenetic data show that strain $\mathrm{XE}^{\mathrm{TP}}$ does not belong to the genus Paenibacillus and is distinct from any other described genus. The creation of a new genus Thermobacillus and a new species Thermobacillus xylanilyticus to accommodate the new isolate is therefore proposed.

\section{Description of Thermobacillus gen. nov.}

Thermobacillus (Ther.mo.ba.cil'lus. Gr. adj. thermos hot; M.L. dim. n. bacillus small rod; M.L. n. Thermobacillus a small thermophilic rod).

Thermobacillus cells are Gram-negative, sporeforming, aerobic, non-motile, rod-shaped, thermophilic bacteria. The menaquinone is MK-7. The major fatty acid is $\mathrm{C} 16: 0$ iso. The $\mathrm{G}+\mathrm{C}$ content is 
$57.5 \mathrm{~mol} \%$. The type species is Thermobacillus xylanilyticus sp. nov.

\section{Description of Thermobacillus xylanilyticus sp. nov.}

Thermobacillus xylanilyticus (xy.la.ni.ly'ti.cus. Gr. n. xylon wood; N.L. n. xylanum xylan, a plant polysaccharide; Gr. adj. lyticus dissolving; M.L. adj. xylanilyticus hydrolysing xylan).

Cells are short rods measuring $0 \cdot 4-0.5$ by $2 \cdot 0-2 \cdot 8 \mu \mathrm{m}$. Non-motile. Ellipsoidal endospores are formed in swollen sporangia. Aerobic. Gram reaction is negative. Colonies are irregular, flat, with undulate margins. Catalase-positive and oxidase- and urease-negative. Growth occurs in the presence of $3 \% \mathrm{NaCl}$. Starch and aesculin are hydrolysed, whereas gelatin and casein are not. Utilizes cellobiose, fructose, galactose, lactose, mannose, melezitol, melibiose, raffinose, trehalose, tributyrin and xylose as sole carbon source for growth. Substrates which are not utilized are adonitol, casein, citrate, dextrin, dulcitol, erythritol, gelatin, inulin, salicin, sorbitol and succinate. Nitrate is not reduced. Thermophilic. Grows optimally at $55^{\circ} \mathrm{C}$; maximum temperature for growth is $63^{\circ} \mathrm{C}$. Grows at $\mathrm{pH}$ 6.5-8.5; optimum $\mathrm{pH}$ is 7.8. $\mathrm{CO}_{2}$ is required. Produces large quantities of a xylan-inducible xylanase in the culture medium. The menaquinone is MK-7. The major fatty acid is $\mathrm{C} 16: 0$ iso. The $\mathrm{G}+\mathrm{C}$ content is $57.5 \mathrm{~mol} \%$ (determined by thermal denaturation). According to the complete 16S rDNA sequence of its only member, this genus belongs to the ClostridiumBacillus subphylum of Gram-positive bacteria. The type species is Thermobacillus xylanilyticus. The type strain is $\mathrm{XE}^{\mathrm{TP}}$, which was isolated in France. The type strain has been deposited in the Collection Nationale de Cultures Microbiennes (CNCM I-1017) as a patent strain.

\section{ACKNOWLEDGEMENTS}

We are indebted to Mrs Hélène Bobichon, EA 2063, Unité MEDIAN, IFR 53, UFR Pharmacie, Reims for performing the electron microscopy. We also thank Françoise Fontaine and Béatrice Hermant for technical assistance. Funding came in part from the Europol'Agro consortium.

\section{REFERENCES}

Annison, G. (1992). Commercial enzyme supplementation of wheat-based diets raises ileal glycanase activities and improves apparent metabolisable energy starch and pentosan digestibilities in broiler chickens. Anim Feed Sci Technol 38, 105-121.

Ash, C., Priest, F. G. \& Collins, M. D. (1993). Molecular identification of rRNA group 3 bacilli (Ash, Farrow, Wallbanks \& Collins) using a PCR probe test - proposal for the creation of a new genus Paenibacillus. Antonie Leeuwenhoek 64, 253-260.

Bergquist, P. L., Love, D. R., Croft, J. E., Streiff, M. B., Daniel, R. M. \& Morgan, H. W. (1989). Genetics and potential biotechnological applications of thermophilic and extremely thermophilic archaebacteria and eubacteria. Biotechnol Genet Eng Rev 5, 199-244.

Brosius, J., Palmer, J. L., Kennedy, J. P. \& Noller, H. F. (1978).
Complete nucleotide sequence of a $16 \mathrm{~S}$ ribosomal RNA gene from Escherichia coli. Proc Natl Acad Sci USA 75, 4801-4805.

Classen, H. L. (1996). Cereal grain starch and exogenous enzymes in poultry diets. Anim Feed Sci Technol 62, 21-27.

Heyndrickx, M., Vandemeulebroecke, K., Hoste, B., Janssen, P., Kersters, K., De Vos, P., Logan, N. A., Ali, N. \& Berkeley, R. C. W. (1996). Reclassification of Paenibacillus (formerly Bacillus) pulvifaciens (Nakamura 1984) Ash et al. 1994, a later subjective synonym of Paenibacillus (formerly Bacillus) larvae (White 1906) Ash et al., 1994, as a subspecies of $P$. larvae, with emended descriptions of $P$. larvae as $P$. larvae subsp. larvae and $P$. larvae subsp. pulvifaciens. Int J Syst Bacteriol 46, 270-279.

Heyndrickx, M., Lebbe, L., Kersters, K., De Vos, P., Forsyth, G. \& Logan, N. A. (1998). Virgibacillus: a new genus to accommodate Bacillus pantothenticus (Proom and Knight 1950). Emended description of Virgibacillus pantothenticus. Int J Syst Bacteriol 48, 99-106.

Kämpfer, P. (1994). Limits and possibilities of total fatty acid analysis for classification and identification of Bacillus species. Syst Appl Microbiol 17, 86-98.

Kimura, M. (1980). A simple method for estimating evolutionary rates of base substitutions through comparative studies of nucleotide sequences. $J$ Mol Evol 16, 111-120.

Kroppenstedt, R. M. (1985). Fatty acid and menaquinone analysis of Actinomycetes and related organisms. In Chemical Methods in Bacterial Systematics, pp. 173-199. Edited by M. Goodfellow \& D. E. Minnikin. London: Academic Press.

Lamed, R., Bayer, E., Saha, B. C. \& Zeikus, J. G. (1988). Biotechnological potential of enzyme from unique thermophiles. In Proceedings of the 8th International Biotechnology Symposium, pp. 371-383. Edited by G. Durand, L. Bobichon \& J. Florent. Paris: French Society for Microbiology.

Maat, J., Roza, M., Verbakel, J. \& 9 other authors (1992). Xylanases and their application in bakery. In Progress in Biotechnology, vol. 7, Xylans and Xylanases, pp. 349-360. Edited by J. Visser, M. A. Kusters van Someren, G. Beldman \& A. G. J. Voragen. Amsterdam: Elsevier.

Maidak, B. L., Olsen, G. J., Larsen, N., Overbeek, R., McCaughey, M. J. \& Woese, C. R. (1997). The RDP (Ribosomal Database Project). Nucleic Acids Res 25, 109-111.

Marmur, J. \& Doty, P. (1962). Determination of the base composition of deoxyribonucleic acid from its thermal denaturation temperature. J Mol Biol 5, 109-118.

Minnikin, D. E., O’Donnell, A. G., Goodfellow, M., Alderson, G., Athalye, M., Schaal, A. \& Parlett, J. H. (1984). An integrated procedure for extraction of bacterial isoprenoid quinones and polar lipids. J Microbiol Methods 2, 233-242.

Mora, F., Comtat, J., Barnoud, F., Pla, F. \& Noé, P. (1986). Action of xylanases on chemical pulp fibers. Part I: Investigations on cell-wall modifications. J Wood Chem Technol 6, 147-165.

Mullis, K. B. \& Faloona, F. A. (1987). Specific synthesis of DNA in vitro via a polymerase-catalysed chain reaction. Methods Enzymol 155, 335-350.

Noé, P., Chevalier, J., Mora, F. \& Comtat, J. (1986). Action of xylanases on chemical pulp fibers. Part II : Enzymatic beating. J Wood Chem Technol 6, 167-184.

Pearson, W. R. (1990). Rapid and sensitive sequence comparison with FASTP and FASTA. Methods Enzymol 183, 63-98.

Pearson, W. R. \& Lipman, D. J. (1988). Improved tools for biological sequence analysis. Proc Natl Acad Sci USA 85, 2444-2448.

Rouau, X., El-Hayek, M.-L. \& Moreau, D. (1994). Effect of an 
enzyme preparation containing pentosanases on the breadmaking quality of flours in relation to changes in pentosan properties. J Cereal Sci 19, 259-272.

Saiki, R. K., Gelfand, D. H., Stoffel, S., Scharf, S. J., Higuchi, R., Horn, G. T., Mullis, K. B. \& Erlich, H. A. (1988). Primer-directed enzymatic amplification of DNA with thermostable DNA polymerase. Science 239, 487-491.

Samain, E., Debeire, P., Debeire-Gosselin, M. \& Touzel, J.P. (1991). Xylanase, souches de Bacillus productrices de xylanases et leurs utilisations. Patent FR-9101191.

Samain, E., Touzel, J. P., Brodel, B. \& Debeire, P. (1992). Isolation of a thermophilic bacterium producing high levels of xylanase. In Progress in Biotechnology, vol. 7, Xylans and Xylanases, pp. 467-470. Edited by J. Visser, M. A. Kusters van Someren, G. Beldman \& A. G. J. Voragen. Amsterdam: Elsevier.

Samain, E., Debeire, P. \& Touzel, J. P. (1997). High level production of a cellulase-free xylanase in glucose-limited fed batch cultures of a thermophilic Bacillus strain. J Biotechnol 58, 71-78.

Sanger, F., Nicklen, S. \& Coulson, A. R. (1977). DNA sequencing with chain-terminating inhibitors. Proc Natl Acad Sci USA 74, 5463-5467.

Shida, O., Tagaki, H., Kadowaki, K. \& Komagata, K. (1996). Proposal of two new genera, Brevibacillus gen. nov. and Aneurinibacillus gen. nov. Int J Syst Bacteriol 46, 939-946.

Shida, O., Tagaki, H., Kadowaki, K., Nakamura, L. K. \& Komagata, K. (1997). Transfer of Bacillus alginolyticus, Bacillus chondroitinus, Bacillus curdlanolyticus, Bacillus glucanolyticus, Bacillus kobensis, and Bacillus thiaminolyticus to the genus Paenibacillus and emended description of the genus Paenibacillus. Int J Syst Bacteriol 47, 289-298.

Smibert, R. M. \& Krieg, N. R. (1994). Phenotypic characterization. In Methods for General and Molecular Bacteriology, pp. 607-654. Edited by P. Gerhardt, R. G. E. Murray, W. A. Wood \& N. R. Krieg. Washington, DC: American Society for Microbiology.

Sneath, P. H. A. (1986). Endospore-forming Gram-positive rods and cocci. Genus Bacillus. In Bergey's Manual of Systematic
Bacteriology, vol. 2, pp. 1104-1139. Edited by P. H. A. Sneath, N. S. Mair, M. E. Sharpe \& J. G. Holt. Baltimore: Williams \& Wilkins.

Touzel, J. P., Conway de Macario, E., Nölling, J., de Vos, W. M., Zhilina, T. \& Lysenko, A. M. (1992). DNA relatedness among some thermophilic members of the genus Methanobacterium: emendation of the species Methanobacterium thermoautotrophicum and rejection of Methanobacterium thermoformicicum as a synonym of Methanobacterium thermoautotrophicum. Int J Syst Bacteriol 42, 408-411.

Van de Peer, Y. \& De Wachter, R. (1994). TREECON for Windows: a software package for the construction and drawing of evolutionary trees for the Microsoft Windows environment. Comput Appl Biosci 10, 569-570.

Viikari, L., Kantelinen, A., Sundquist, J. \& Linko, M. (1994). Xylanases in bleaching: from an idea to the industry. FEMS Microbiol Rev 13, 335-350.

Wassermann, B. P. (1984). Thermostable enzyme production. Food Technol 38, 78-89.

Wisotzkey, J. D., Jurtshuk, P., Jr, Fox, G. E., Deinhard, G. \& Poralla, K. (1992). Comparative sequence analyses on the $16 \mathrm{~S}$ rRNA (rDNA) of Bacillus acidocaldarius, Bacillus acidoterrestris, and Bacillus cycloheptanicus and proposal for creation of a new genus, Alicyclobacillus gen. nov. Int J Syst Bacteriol 42, 263-269.

Wong, K. K. Y., Nelson, S. L. \& Saddler, J. N. (1996). Xylanase treatment for the peroxide bleaching of oxygen delignified kraft pulps derived from three softwood species. J Biotechnol 48, 137-145.

Yoon, J.-H., Yim, D. K., Lee, J.-S., Shin, K.-S., Sato, H. H., Lee, S. T., Park, Y. K. \& Park, Y.-H. (1998). Paenibacillus campinasensis sp. nov., a cyclodextrin-producing bacterium isolated in Brazil. Int J Syst Bacteriol 48, 833-837.

Zeikus, J. G. (1979). Thermophilic bacteria: ecology, physiology and technology. Enzyme Microb Technol 1, 243-252.

Zeikus, J. G. \& Wolfe, R. S. (1972). Methanobacterium thermoautotrophicus sp. nov., an anaerobic, autotrophic extreme thermophile. J Bacteriol 109, 707-713. 